\title{
PERANAN AUDIT OPERASIONAL DALAM RANGKA EFEKTIVITAS PENGENDALIAN BIAYA OPERASIONAL PADA BPR BANK PASAR KOTA BOGOR
}

\author{
Tiara Timuriana \\ Dosen Tetap Fakultas Ekonomi \\ Universitas Pakuan \\ Ani Ganitasari \\ Mahasiswa Fakultas Ekonomi \\ Universitas Pakuan
}

\begin{abstract}
ABSTRAK
Dalam melaksanakan kegiatan operasionalnya bank membutuhkan biaya operasional. Biaya operasional dibutuhkan untuk mendukung kegiatan operasional yang meliputi pengadaan sarana dan prasarana, peningkatan Sumber daya Manusia, penghimpunan dan penyaluran dana. Untuk mencegah penyalahgunaan biaya dan meminimalisasi ketidakefektivan, maka dibutuhkan peranan audit operasional.

PD BPR Bank Pasar Kota bogor merupakan salah satu Badan Usaha Milik Pemerintah Daerah Kota Bogor yang bergerak dalam bidang pelayanan jasa perbankan, baik beupa simpanan yang berbentuk tabungan atau deposito maupun pinjaman uang yang diperuntukan bagi masyarakat pedagang kecil dalam rangka pengembangan usahanya maupun kepada Pegawai Negeri Sipil, Pensiunan, Pegawai Swasta di wilayah Kota Bogor.

Tujuan penelitian ini, untuk mengetahui pengelolaan dan pengendalian biaya operasional, mengetahui pelaksanaan audit operasional, dan mengetahui peranan audit operasional dalam rangka efektivitas pengendalian biaya operasional di PD BPR Bank Pasar Kota Bogor.

Penelitian ini dilakukan dengan metode uji kualitatif terhadap kuesioner peranan audit operasional yang mengacu pada tahapan audit operasional. Hasil pengujian menunjukkan pelaksanaan audit operasional dinilai sesuai dengan tahapan pelaksanaan, peranan audit operasional kurang berperan secara maksimal, sedangkan pengelolaan dan pengendalian biaya operasional belum maksimal karena adanya realisasi yang masih lebih besar dari anggarannya.
\end{abstract}

Kata kunci: Audit pendahuluan atas biaya operasional, Revieuw dan pengujian pengendalian manajemen operasional, Audit terinci atas biaya operasional, Pelaporan, Tindak lanjut, Pemisahan Tugas, Pengendalian Fisik, Respon terhadap kinerja.

\section{Pendahuluan}

Sejalan dengan berkembangnya perusahaan menyebabkan semakin bertambahnya masalah yang dihadapi pimpinan perusahaan, salah satunya dalam menghadapi situasi bisnis 
Peranan Audit Operasional dalam Rangka Efektivitas Pengendalian Biaya Operasional pada BPR Bank Pasar Kota Bogor

yang semakin kompetitif. Bank termasuk perusahaan jasa karena kegiatannya memberikan pelayanan jasa kepada masyarakat. Bank merupakan lembaga keuangan yang menghimpun dana masyarakat dalam bentuk simpanan dan menyalurkannya dalam bentuk kredit kepada masyarakat yang membutuhkan dana.

Dalam melaksanakan kegiatan operasionalnya, bank membutuhkan biaya operasional. Biaya operasional dibutuhkan untuk mendukung kegiatan operasional yang meliputi pengadaan sarana dan prasarana, peningkatan sumber daya manusia, penghimpun dana masyarakat dalam bentuk tabungan dan deposito, penyaluran dana dalam bentuk kredit.

Audit operasional dapat dilakukan untuk penyalahgunaan biaya dan meminimalisasi ketidakefektifan yang terjadi dalam kegiatan operasi. Melalui audit operasional, pihak manajemen perusahaan dapat mengetahui pelaksanaan kegiatan operasi, masalah yang ada dalam kegiatan tersebut dan cara untuk mengatasi masalah. Dengan demikian, auditor dapat memberikan informasi yang diperlukan untuk membantu para pengelola perusahaan dalam proses pengambilan keputusan agar tujuan perusahaan tercapai dengan baik.

PD BPR Bank Pasar Kota Bogor merupakan salah satu BUMD Kota Bogor yang bergerak dalam bidang pelayanan jasa perbankan berupa simpanan berbentuk tabungan dan deposito maupun pinjaman uang yang diperuntukkan bagi masyarakat pedagang kecil dan sebagainya.

Permasalahan yang terjadi di PD BPR Bank Pasar Kota Bogor, adalah pengelolaan dan pengendalian terhadap biaya operasional belum maksimal yang mengakibatkan banyak biaya yang dikeluarkan.

Oleh karena itu, Tujuan penelitian adalah sebagai berikut: 1) Untuk menngetahui pengelolaan dan pengendalian biaya operasional pada PD BPR Bank Pasar Kota Bogor; 2) Untuk mengetahui pelaksanaan audit operasional pada PD BPR Bank Pasar Kota Bogor; 3) Untuk mengetahui peranan audit operasional dalam rangka efektivitas pengendalian biaya operasional pada PD BPR Bank Pasar Kota Bogor.

\section{Metode Penelitian}

Metode penelitian yang digunakan adalah deskriptif kualitatif (nonstatistik), yaitu penelitian yang bertujuan untuk menggambarkan keadaan atau suatu fenomena tertentu serta mengumpulkan data yang relevan yang tersedia kemudian disusun, dipelajari, dan dianalisis lebih lanjut. Penelitian dilakukan tidak dengan alat analisis statistik, namun menggunakan kerangka teoritis sebagai alat analisisnya. 
Penelitian dilakukan berkaitan dengan dokumen dari tahun 2007 sampai dengan tahun 2009. Data tersebut berupa laporan keuangan, anggaran biaya operasional.

Dengan menggunakan metode Deskriptif Kualitatif (nonstatistik) diharapkan dapat menjelaskan tentang kebijakan dan prosedur dalam meningkatkan efektivitas pengendalian biaya operasional, sehingga diperoleh gambaran mengenai peranan audit operasional dalam rangka efektivitas pengendalian biaya operasional.

\section{Hasil dan Pembahasan}

\subsection{Rencana dan Realisasi Biaya Operasional PD BPR Bank Pasar Kota Bogor}

Suatu operasi dikatakan efektif apabila tujuan perusahaan telah tercapai target dalam pelayanan yang diharapkan. Untuk mengetahui tingkat efektivitas biaya operasional perusahaan, penulis menggunakan data yang diambil dari bagian Laporan Laba/Rugi PD BPR Bank Pasar Kota Bogor.

Berdasarkan data yang diperoleh, dapat disimpulkan bahwa beban bunga, beban personalia melebihi anggaran biaya operasi, akibatnya realisasi biaya operasi yang dikeluarkan tidak sesuai dengan yang dianggarkan. Dari data yang ada, anggaran biaya operasi sebesar Rp 6.721.016 dan realisasi biaya operasi Rp 6.356.032, maka pencapaian anggaran biaya operasi $94 \%$ artinya anggaran biaya operasi yang ditetapkan oleh pihak perusahaan tercapai dengan selisih sebesar Rp 364.984. dapat dilihat selama periode yang diteliti terjadi penyimpangan yang menguntungkan dan merugikan.

Berdasarkan penelitian yang dilakukan terhadap proses penyusunan anggaran biaya operasi yang ditetapkan PD BPR Bank Pasar Kota Bogor terlihat bahwa proses penyusunan cukup baik. Sedangkan, pelaksanaan dari anggaran biaya operasi kurang memuaskan.

\subsection{Pengendalian terhadap biaya operasional PD BPR Bank Pasar Kota Bogor.}

Supaya biaya operasional bisa efektif dan efisiensi maka diperlukan pengendalian biaya operasional dapat dilakukan dengan beberapa cara:

1. Pemisahan Tugas

2. Pengendalian fisik terhadap dokumen

3. Menetapkan anggaran sebagai dasar dalam melaksanakan pengukuran biaya operasi.

4. Memnbandingan realisasi biaya dengan anggaran 


\subsection{Pelaksanaan Audit operasional atas biaya operasional PD BPR Bank Pasar Kota Bogor.}

Dalam melaksanakan audit, Satuan pengawasan intern (SPI) melakukan setiap fungsi audit operasional. Melakukan audit terhadap semua kegiatan kredit, tabungan, biaya dan rasio-rasio. Adapun tahapan dalam pelaksanaan audit operasional sebagai berikut:

1. Tahap Audit Pendahuluan

2. Tahap Revieuw dan Pengujian Pengendalian

3. Tahap Audit Terinci

4. Tahap Pelaporan

5. Tahap Tindak Lanjut

\subsection{Tahap Audit Pendahuluan atas biaya Biaya operasional PD BPR Bank Pasar}

\section{Kota Bogor.}

Langkah awal yang dilakukan oleh satuan pengawasan intern (SPI) adalah memantau kegiatan secara keseluruhan, sehingga satuan pengawasan intern mengetahui keadaan yang akan diaudit. Setelah memantau kegiatan secara keseluruhan satuan pengawasan intern (SPI) mencari data tertulis seperti bukti transaksi.

Pada tahap ini, berdasarkan data yang diperoleh satuan pengawasan intern (SPI) melakukan:

1. Pemeriksaanterhadap transaksi-transaksi. Tujuannya untuk mengendalikan pengeluaran, penerimaan, biaya-biaya serta harta.

2. Pemeriksaan bukti pengeluaran operasi.

3. Pemeriksaan terhadap efisisensi pemakaian sumber dana dan dapat silakukan dengan memeriksa daftar pengeluaran.

\subsection{Peranan Audit operasional dalam rangka efektivitas pengendalian biaya}

Biaya operasional di PD BPR Bank Pasar Kota Bogor jika dilihat dari total anggaran dan realisasi pengelolaan serta penyusunan biaya operasional sudah baik. Akan tetapi, dalam prakteknya jika dilihat dari pos-pos biaya operasional antara anggaran dan realisasi terdapat penyimpangan yang menguntungkan dan merugikan bagi pihak perusahaan. Penyimpangan tersebut terjadi karena adanya pengendalian dan pengelolaan biaya belum maksimal. Penyimpangan yang menguntungkan pihak perusahaan dapat dilihat dari:

1. Realisasi lebih kecil dari anggarannya. 
2. Biaya yang dikeluarkan dapat terlaksana pada tahun anggaran ini sehingga tidak mengganggu aktivitas operasi perusahaan.

3. Adanya pengurangan anggaran dari tahun ke tahun

Sedangkan, penyimpangan yang merugikan pihak perusahaan dapat dilihat dari:

1. Realisasi lebih besar dari anggarannya.

2. Keterlambatan biaya yang dilakukan untuk keperluan aktivitas operasi perusahaan karena tidak sesuai dengan anggaran terpaksa ditunda untuk tahun anggaran berikutnya.

3. Terhambatnya kegiatan operasional yang menjadi tujuan utama organisasi ini.

Jika dilihat dari penyimpangan di atas, maka dapat dilakukan suatu pengendalian terhadap biaya operasional dengan:

1. Adanya pemisahan tugas diantara bagian-bagian unit organisasi.

2. Adanya pengendalian fisik dapat dilakukan dengan menyimpan dokumen penting di tempat yang aman dengan kunci ganda dan memakai nomor kode.

3. Menetapkan anggaran dasar.

4. Membandingkan realisasi dengan anggarannya.

Dalam pelaksanaan audit operasional, auditor internal maupun eksternal melakukan pemantauan secara keseluruhan terhadap aktivitas kegiatan serta mengumpulkan bukti. Selanjutnya, memeriksa bukti tersebut hingga ditemukannya sebuah temuan/permasalahan. Temuan disini yaitu laporan biaya operasional tidak sesuai dengan anggaran biaya operasional yang disebabkan pengelolaan dan pengendalian biaya operasional belum maksimal. Hal itu akan berdampak terjadinya penyimpangan program pengendalian biaya operasional.

Pengelolaan dan pengendalian biaya operasional yang kurang maksimal sangat membutuhkan peranan audit internasional dalam rangka efektivitas pengendalian biaya operasional. Berikut ini adalah tujuan peranan audit operasional di PD BPR Bank Pasar Kota Bogor sebagai berikut:

1. Mengendalikan biaya operasi agar sesuai dengan anggaran sehingga dapat memperoleh hasil yang sebesar-besarnya denga biaya sekecil mungkin.

2. Dalam penyelenggaraan audit atas administrasi keuangan dan pengelolaan penggunaan seluruh kekayaan milik PD BPR Bank Pasar Kota Bogor.

3. Melakukan pengawasan dan pemberian penilaian terhadap kegiatan operasional.

4. Membantu pihak direksi dalam mengelola aktivitas operasi. 
5. Berbagai temuan dan rekomendasi yang berhubungan dengan pelaksanaan audit operasional atas pengendalian biaya operasi telah dilakukan tindak lanjut.

6. Dengan adanya audit operasional tujuan operasi yang telah ditetapkan dapat dicapai.

Dari kondisi pengelolaan dan pengendalian biaya serta peranan audit operasional yang masih kurang maksimal memberikan dampak sebgai berikut:

1. Realisasi masih lebih besar dari anggarannya.

2. Tertundanya biaya yang dikeluarkan karena tidak sesuai dengan anggaran yang terpaksa harus ditunda.

3. Terhambatnya kegiatan operasional akibat tertundanya biaya tersebut.

\section{Simpulan}

Berdasarkan penelitian yang telah dilakukan serta didukung dengan data yang diperoleh dari hasil penelitian, terdapat beberapa hal yang dapat disimpulkan yaitu:

1. Pelaksanaan pengendalian dan pengelolaan biaya operasional yang dilakukan oleh PD BPR Bank Pasar Kota Bogor masih belum maksimal, hal ini dapat berdampak terjadinya penyimpangan pengendalian biaya operasional. Berikut ini adalah penyimpangan yang memberikan dampak negative bagi pihak perusahaan, yaitu:

a. Realisasi lebih besar dari anggaran

b. Keterlambatan biaya yang dikeluarkan untuk keperluan aktivitas operasi perusahaan karena tidak sesuai dengan anggaran terpaksa ditunda untuk tahun anggaran berikutnya.

c. Terhambatnya kegiatan operasional yang menjadi tujuan utama organisasi.

2. Pelaksanaan audit operasional pada PD BPR Bank Pasar Kota Bogor cukup baik. Hal itu ditandai dengan dilakukan oleh orang ynag berkompeten dan sesuai dengan tahapan pelaksanaan audit operasional mulai dari tahap audit pendahuluan sampai tahap tindak lanjut. Menguasai dan memeriksa dokumen-dokumen, formulir-formulir, serta bukti yang berkaitan dengan pengeluaran, penerimaan, biaya-biaya serta harta. Serta ikut terlibat langsung dalam pengawasan pelaksanaan tindak lanjut bertujuan agar mempercepat penanggulangan kelemahan.

3. Peranan audit operasional di PD BPR Bank Pasar Kota Bogor kurang bermanfaat karena belum bisa mendorong terjadinya efektivitas pengendalian biaya operasional, walaupun dengan adanya peranan audit operasional masih saja dalam pos-pos biaya operasional antara anggaran dan realisasi masih lebih besar realisasi disebabkan 
karena pengelolaan dan pengendalian biaya operasional belum maksimal, yang berdampak terjadinya penyimpanga biaya operasional. Penyimpangan tersebut dapat menghambat kegiatan operasional di PD BPR Bank Pasar Kota Bogor, tertundanya biaya yang dikeluarkan dan terhambatnya kegiatan operasional akibat tertundanya biaya tersebut.

\section{Daftar Pustaka}

Arens, Alvin A., Randal J elder dan Mark S Beasley. 2008. Auditing dan Jasa Assurance. Edisi Keduabelas, Jilid I dan II, Alih Bahasa. Herman Wibowo, Gina Gania. Jakarta: Penerbit Erlangga.

Boynton William C., Raymond N, Johnson, Walter G Kell. 2001. Modern Auditing. Seven Edition, New York: John Willey and Sons Inc.

Boynton William C., Raymond N, Johnson, Walter G. Kell. 2003. Modern Auditing. Alih Bahasa: Paul A Rajoe, Gina Gania, Ichsan Setiyo Budi, Herman Wibowo. Edisi Ketujuh, Jilid I dan II, Jakarta: Penerbit Erlangga.

Ferry N. Idroes dan Sugiarto. 2006. Manajemen Risiko Perbankan dalam Konteks Kesepakatan Basel dan Peraturan Bank Indonesia. Edisi Pertama, Jakarta: Penerbit Erlangga.

Guy, dan M, C. Wayne Alderman, Alan, J. Winters. 2003. Auditing. Alih Bahasa: Paul A, Rajoe, Ichsan Setiyo Budi. Edisi Kelima, Jilid II. Jakarta: Penerbit Erlangga.

Hasibuan, Malayu. S.P. 2008. Dasar-dasar Perbankan. Cetakan Ketujuh, Jakarta: PT Bumi Aksara.

H R Daeng Naja. 2006. Legal Audit Operasional Bank. Cetakan Pertama, Bandung: PT Citra Aditya Bakti.

IBK Bayangkara. 2008. Audi Manajemen: Prosedur dan Implementasi. Jakarta: Salemba Empat. 